\title{
PENGARUH ILLUSIONS OF CONTROL, OVERCONFIDENCE DAN EMOTION TERHADAP PENGAMBILAN KEPUTUSAN INVESTASI PADA INVESTOR DI YOGYAKARTA
}

\author{
Kartini' dan Nuris Firmansyah Nugraha ${ }^{2}$ \\ 1,2 Prodi Manajemen Universitas Islam Indonesia \\ Email: kartini@uii.ac.id
}

\begin{abstract}
Nowadays Investors often make investment decision irrationally. The decision is often based on their judgment that is far away from rational assumption. When investors face risky situa-tion, there are some objectivities, emotions, and other psychological factors that usually ef-fect their decision making. This purpose of study is to examine the effect of illusions of control, risk tolerance, overconfidence and emotion on investment decision making among investors in yogyakarta. Sample of this study is the investors who are 17 until 40 years old and investing in stocks. This study used purposive, convenience and snow-ball sampling method. There are 86 respondents taken from questionnaire. To test hypotheses, this study employs descriptive analysis and multiple regression analysis. Moreover, by performing multiple regression analysis, this study found that illusions of control does not have a negative significant while overconfidence has a positive significant and emotion has a negative significant influance to the investment decision.
\end{abstract}

Key words: Investment Decision Making, illusions of control, overconfidence and emotion.

\section{PENDAHULUAN}

Pengambilan keputusan merupakan fenomena yang kompleks, meliputi semua aspek kehidupan, mencakup berbagai dimensi, dan proses memilih dari berbagai pilihan yang tersedia. Teori pengambilan keputusan didasari oleh konsep kepuasan, bahwa ini individu dapat menentukan meningkat atau menurunnya utilitas dalam upaya meningkatkan kepuasan.Berdasarkan konsep ini, setiap tindakan individu bertujuan untuk memaksimalkan jumlah utilitas untuk mencapai kepuasan.Demikian halnya, pengambilan keputusan investasi oleh investor dilakukan secara rasional dalam rangka memaksimalkan utilitasnya.Para investor secara rata-rata memanfaatkan informasi akuntansi keuangan sebagai pertimbangan dalam keputusan investasinya (Puspitaningtyas, 2012).
Konsep mengenai investor (individu) yang rasional dalam teori pengambilan keputusan bermakna bahwa dalam mengambil keputusan, tindakan yang dipilih adalah tindakan yang akan menghasilkan utilitas (utility) tertinggi yang diharapkan (Puspitaningtyas, 2012). Investor yang rasional akan melakukan analisis dalam proses pengambilan keputusan investasi. Analisis yang dilakukan antara lain dengan mempelajari laporan keuangan perusahaan, serta mengevaluasi kinerja bisnis perusahaan. Tujuannya ialah keputusan investasi yang diambil akan memberikan kepuasan yang optimal.

Pada kenyataanya seringkali kita temukan bahwa individu berperilaku tidak rasional dan membuat kesalahan sistematis atas peramalan yang mereka lakukan. Sekarang ini, para pelaku keuangan menyadari bahwa individu dapat mengambil keputusan yang tak 
rasional. Pengertian yang salah terhadap informasi akan mempengaruhi hasil investasi yang pada akhirnya mempengaruhi kekayaan yang dimiliki investor. Walau sudah menjadi pakar dalam teori dari buku-buku ajar investasi modern pun, investor akan tetap gagal dalam berinvestasi apabila keputusan yang diambil masih sangat dipengaruhi oleh bias psikologis (Bester, 2009).

Penelitian-penelitian yang dilakukan selama beberapa dekade terakhir menunjukkan bahwa investor seringkali bertindak secara tidak rasional dan seringkali ditemukan fenomena dalam pasar modal dan pasar keuangan yang bertentangan dengan teori keuangan standar (teori keuangan tradisional). Dalam teori keuangan tradisional ini mengabaikan aspek-aspek psikologis dalam proses pengambilan keputusan investor (Ricciardi dan Simon, 2000). Adanya alasan ini, perilaku investor banyak yang tidak bisa dijelaskan dalam konteks teori keuangan tradisional.Menyadari ketidakmampuan teori keuangan tradisional (traditional finance) untuk menjelaskan anomali dalam fenomena pasar uang dan pasar modal, maka para peneliti keuangan mulai mengkaitkan fenomena yang ada dengan aspek perilaku (behavioralfinance).Menyadari

ketidakmampuan traditional finance untuk menjelaskan anomaly dalam fenomena pasar uang dan pasar modal, maka para peneliti keuangan mulai mengkaitkan fenomena yang ada dengan aspek perilaku (behavioral finance).

Pengambil keputusan memiliki kemungkinan untuk mengambil keputusan yang salah atau perkiraan yang melenceng. Kondisi ini membahayakan karena tidak dapat dilihat dan terkait langsung dengan proses pemikiran. Bias mengakibatkan kesalahan prediksi, karena dapat membuat orang salah dalam memperhitungkan risiko yang dapat terjadi. Hal ini menjadi ketertarikan untuk membahas mengenai aspek bias. Bias dalam penelitian ini diantaranya

Illusion of control dideskripsikan sebagai suatu keyakinan yang lebih dalam hal kemampuan untuk memprediksi atau hasil yang lebih memuaskan ketika seseorang memiliki keterlibatan yang lebih di dalamnya ( Langer dan Roth : 1975). Sedangkan Overconfidence adalah perasaan percaya diri secara berlebihan, Overconfidence akan membuat investor menjadi overestimate terhadap pengetahuan yang dimiliki oleh investor itu sendiri, dan underestimate terhadap prediksi yang dilakukan karena investor melebih-lebihkan kemampuan yang dimiliki (Nofsinger, 2005). Overconfidence juga dapat menyebabkan investor menanggung risiko yang lebih besar dalam pengambilan keputusan untuk berinvestasi. Dengan kata lain orang yang overconfidence lebih memandang suatu risiko itu rendah dan sebaliknya, orang yang tidak overconfidence lebih memandang suatu risiko itu tinggi. Sedangkan Emotion merupakan bagian penting dalam proses pengambilan keputusan-keputusan yang memiliki tingkat ketidakpastian yang tinggi. Emotion merupakan bagian penting dalam proses pengambilan keputusan-keputusan yang memiliki tingkat ketidakpastian tinggi. Dalam teorinya emosi merupakan bagian yang penting dalam proses pengambilan keputusan terutama untuk keputusan-keputusan yang memiliki tingkat ketidakpastian yang tinggi. Pada saat goodmood investor dapat mengambil keputusan dengan baik dan benar, sebaliknya pada saat badmood investor tidak dapat mengambil keputusan dengan baik dan benar (Nofsinger, 2010).

Merujuk pada latar belakang tersebut tersebut, kemudian penelitian ini akan meneliti pengaruh illusions of control, overconfidence dan emotion pada pengambilan keputusan investasi pada investor di yogyakarta"

\section{METODE}

\section{A. Pengambilan Keputusan Investasi}

Salah satu faktor yang sangat penting dalam berbagai hal kehidupan adalah pengambilan keputusan. Bagi para pemodal atau investor kesuksesan atau keberhasilan dalam berinvestasi adalah tergantung pada pengambilan keputusan yang dilakukan 
karena hal ini berdampak pada manfaat atau return yang akan diperoleh. Oleh karena itu dinamika pengambilan keputusan telah diteliti dan berkembang menjadi ilmu yang mengandung teori-teori tentang decision science atau pengambilan keputusan dalam berbagai jenis dan lingkungan kehidupan masyarakat. Salah satu teori tersebut yang kemudian menjadi bagian dari berbagai disiplin ilmu seperti psikologi, manajemen, ekonomika, akuntansi dan sosiologi (Plous, 1993). Didalam proses pengambilan keputusan ada dua pendekatan yang bisa dilakukan yaitu pendekatan rasional (rational approach) dan pendekatan irrasional (behavioral approach).

Pendekatan pengambilan keputusan rasional pada awalnya berkembang dengan teori yang disebut expected utility theory yang menyatakan bahwa manusia mengambil keputusan berdasarkan pertimbangan nilai manfaat bersih maksimum yang diperoleh dari keputusan yang diambil (Plous, 1993). Pendekatan ini pada umumnya digunakan dalam pengambilan keputusan masalah ekonomi dan keuangan, dimana pendekatan tersebut menitik beratkan pada analisa cost and benefit dengan menggunakan alat statistik dan ekonometrika. Pendekatan irrasional atau sering disebut juga dengan pendekatan behavioral yaitu pendekatan keperilakuan, dimana pendekatan ini saat ini dikembangan dalam berbagai disiplin ilmu misalnya ekonomika, keuangan, pemasaran, akuntansi, psikologi bahkan sosiologi.

\section{B. Illusions of control}

Investor pasar modal saat ini cenderung melakukan sendiritransaksi portofolio mereka.Jika dalam beberapa tahun lalu para investorbiasanya mempercayakan investasi mereka kepada manajer portofolio,saat ini mereka cenderung melakukan sendiri. Landasan dasar prilakuinvestor ini didasari oleh dua asumsi, yaitu mereka cenderung beranggapan dapat membuat keputusan yang rasional, serta keyakinanmereka atas prediksi yang dibuat.
Istilah illusion of control sendiri pertama kali dikemukakan oleh Langer pada tahun 1975 dalam journal of Personality and Social Psychology. Illusion of control dapat diartikan sebagai fenomena dimana seseorang percaya bahwa dia (seakan-akan) bisa mengendalikan lingkungan sekitarnya walaupun pada kenyataan yang sebenarnya tidak ( Langer,1975). Di masa lalu banyak investor mempercayakan dananya kepada salah satu institusi keuangan, dan keputusan menempatkan investasi diambil oleh manajer investasi profesional.Sekarang investor lebih memilih untuk mengambil keputusan sendiri berdasarkan interpretasi yang diyakininya benar. Semakin tinggi illusion of control semakin sering atau semakin aktif investor dalam mengambil keputusan investasi.

\section{Overconfidence}

Overconfidence adalah perasaan percayadirii secara berlebihan. Overconfidence akan membuat investor menjadi overestimate terhadap pengetahuan yang dimilikioleh investor itu sendiri, dan underestimate terhadap prediksi yang dilakukan karena investor melebih-lebihkan kemampuan yang dimiliki (Nofsinger, 2005). Overconfidence juga akan mempengaruhi inves-tor dalam berperilaku mengambil risiko, dimana investor yang rasional berusaha untuk memaksimalkan keuntungan sementara memperkecil jumlah dari risiko yang diam-bil (Nofsinger, 2005).

\section{Emotion}

Emosi berasal dari bahasa Latin, yaitu emovere, yang berarti bergerak menjauh. Arti kata ini menyiratkan bahwa kecenderungan bertindak merupakan hal mutlak dalam emosi.Daniel Goleman (2002) mengatakan bahwa emosi merujuk pada suatu perasaan dan pikiran yang khas, suatu keadaan biologis dan psikologis dan serangkaian kecenderungan untuk bertindak.

Di dalam pengambilan keputusan investasi emosi dikaitkan dengan adanaya badmood atau goodmood seorang investor yang dapat mempengaruhi dalam transaksi jual beli 
saham dibursa. Emosi merupakan bagian penting dalam proses pengambilan keputusan-keputusan yang memiliki tingkat ketidakpastianyang tinggi (Nofsinger, 2005). Pada suatu saat goodmood investor dapat mengembil keputusan dengan baik dan benar, sebaliknya pada saat badmood investor cenderung tidak dapat mengambil keputusan dengan baik dan benar.

\section{E. Kerangka Pemikiran}

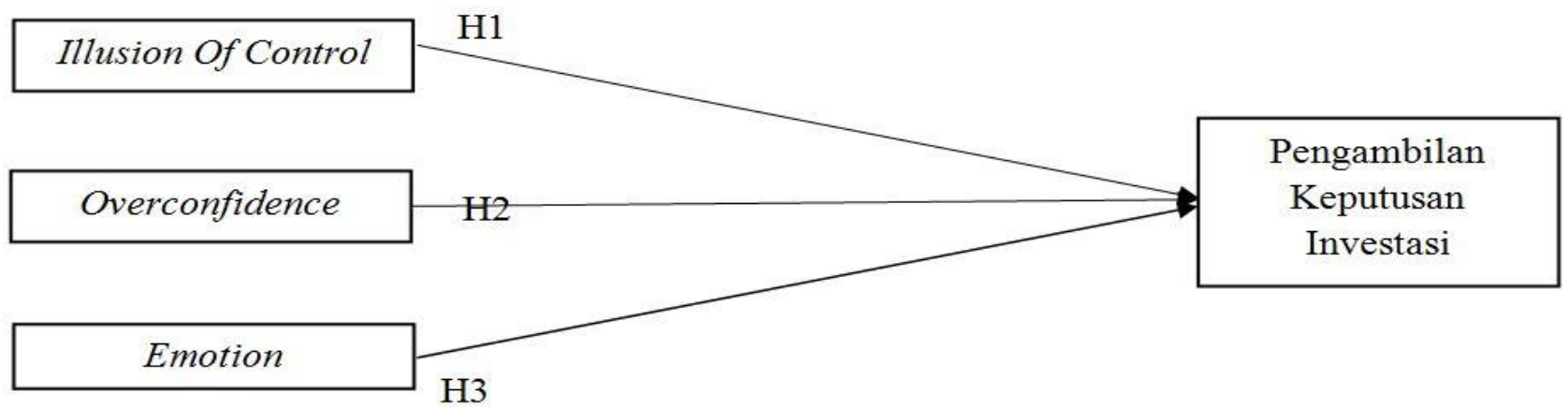

\section{F. Pengembangan Hipotesis}

Hipotesis dalam penelitian ini dirumuskan sebagai berikut:

$\mathrm{H} 1$ : Illusion of control berpengaruh terhadap

Pengambilan Keputusan Investasi

H2: Overconfidence berpengaruh terhadap Pengambilan Keputusan Investasi.

H3: Emotion berpengaruh terhadap Pengambilan Keputusan Investasi.

\section{G. Populasi dan Sampel Penelitian}

Populasi dalam penelitian ini adalah investor yang berada di Yogyakarta.Investor yang dimaksud adalah investor pada investasi financial.

Teknik pengambilan sampel yang digunakan adalah teknik non random sampling yaitu metode purposive sampling. Selain itu, penelitian ini juga menggunakan teknik convenience sampling, Seseorang diambil sebagai sampel karena kebetulan orang tadi ada di situ atau kebetulan dia mengenal orang tersebut. Selanjutnya,penelitian ini juga menggunakan metode snowball sampling. Metode ini merupakan teknik pengambilan sampel dengan secara berantai (multi level). Pengambilan sampel dengan cara mencari contoh sampel dari populasi yang diinginkan, kemudian dari sampel yang didapat dimintai partisipasinya untuk memilih komunitasnya sebagai sampel lagi. Seterusnya sehingga jumlah sampelyang diinginkan terpenuhi.
Sampel dalam penelitian ini adalah investor yang berumur 17 hingga 40 tahun dan berinvestasi di saham.

Sumber data yang digunakan dalam penelitian ini adalah data primer, yaitu data yang diperoleh secara langsung dari responden. Metode pengumpulan datanya sendiri dilakukan dengan menggunakan kuesioner. Kueisioner diberikan dengan cara yaitu kepada responden secara langsung untuk memastikan bahwa kuesionernya dapat dikembalikan lagi kepada si peneliti sendiri. Pada penelitian ini, data diukur dari tanggapan responden atas pertanyaanpertanyaan yang diajukan melalui kueisioner.

\section{HASIL DAN PEMBAHASAN}

\section{A. Statistik Deskriptif}

Statistik deskriptif adalah statistik yang menggambarkan fenomena atau karakteristik dari data. Karakteristik yang digambarkan adalah karakteristik distribusinya.Analisis statistik digunakan untuk memberikan gambaran dari suatu data yang dilihat dari minimum, maksimum, mean, dan standar deviasi (SD). Pada penelitian ini menggunakan variabel Illusion of control, Overconfidence dan Emotion terhadap pengambilan keputusan investasi akan diuji secara deskriptif seperti yang terlihat dalam tabel 1 berikut: 
Tabel 1. Uji Statistik Deskriptif

Descriptive Statistics

\begin{tabular}{|l|r|r|r|r|r|}
\hline & \multicolumn{1}{|c|}{ N } & Minimum & Maximum & Mean & Std. Deviation \\
\hline IOC & 86 & 8 & 15 & 12.34 & 1.325 \\
OV & 86 & 12 & 30 & 20.66 & 3.370 \\
EM & 86 & 13 & 28 & 21.66 & 3.553 \\
PK & 86 & 9 & 16 & 13.45 & 1.657 \\
Valid N (listwise) & 86 & & & & \\
\hline
\end{tabular}

Tabel 4.1 menjelaskan bahwa pada variable illusions of control memiliki nilai minimum 8 dan maksimum 15 serta nilai ratarata sebesar 12.34 dengan standar deviasi 1.325 , overconfidence memiliki nilai minimum 12 dan maksimum 30 serta nilai rata-rata sebesar 20.66 dengan standar deviasi 3.370, emotion memiliki nilai minimum 13 dan maksimum 28 sertanilai rata-rata sebesar 21.66 dengan standar deviasi 3.553, pengambilan keputusan investasi memiliki nilai minimum 9 dan maksimum 16 sertanilai rata-rata sebesar 13.45 dengan standar deviasi 1.657.

\section{B. Uji Validitas}

Pengujian ini dilakukan dengan membandingkan $r$ hitung (tabel corrected item - total correlation) dengan $r$ tabel (Tabel product moment dengan signifikan 0,05 ) untuk degree of freedom(df) = n-2, dimana " $n$ " adalah jumlah sampel penelitian sebanyak 86 respoden sehingga diperoleh nilai $(\mathrm{df})=86-2$ atau nilai df dari 90 adalah 0,173 , suatu kuesioner dinyatakan valid apabila $r$ hitung $>r$ tabel (Ghozali, 2005). Jika r hitung lebih besar dari $r$ tabel dan bernilai positif maka butir pernyataan atau indikator tersebut dinyatakan valid

Tabel 2. Hasil Uji Validitas

\begin{tabular}{|c|c|c|c|c|}
\hline Variabel & Atribut & r Tabel & r Hitung & Keterangan \\
\hline \multirow[t]{4}{*}{ Illusions of control } & IOC 1 & 0.173 & 0.858 & VALID \\
\hline & 1002 & 0.173 & 0.845 & VALID \\
\hline & 1003 & 0.173 & 0.749 & VALID \\
\hline & IOC 4 & 0.173 & 0.545 & VALID \\
\hline \multirow[t]{6}{*}{ Overconfidence } & OV 1 & 0.173 & 0.728 & VALID \\
\hline & OV 2 & 0.173 & 0.728 & VALID \\
\hline & OV 3 & 0.173 & 0.686 & VALID \\
\hline & OV 4 & 0.173 & 0.850 & VALID \\
\hline & OV 5 & 0.173 & 0.813 & VALID \\
\hline & OV 6 & 0.173 & 0.765 & VALID \\
\hline \multirow[t]{6}{*}{ Emotion } & EM 1 & 0.173 & 0.717 & VALID \\
\hline & EM 2 & 0.173 & 0.652 & VALID \\
\hline & EM 3 & 0.173 & 0.733 & VALID \\
\hline & EM 4 & 0.173 & 0.826 & VALID \\
\hline & EM 5 & 0.173 & 0.783 & VALID \\
\hline & EM 6 & 0.173 & 0.760 & VALID \\
\hline \multirow{4}{*}{$\begin{array}{l}\text { Pengambilan } \\
\text { Keputusan Investasi }\end{array}$} & PK 1 & 0.173 & 0.868 & VALID \\
\hline & PK 2 & 0.173 & 0.778 & VALID \\
\hline & PK 3 & 0.173 & 0.851 & VALID \\
\hline & PK 4 & 0.173 & 0.713 & VALID \\
\hline
\end{tabular}


Berdasarkan tabel 4.2 menunjukkan bahwa seluruh item peryataan yang terdiri dari masing-masing variabel dapat dinyatakan valid karena $r$ hitung lebih besar dari $r$ tabel, dengan demikian seluruh butir pernyataan dapat digunakan untuk dapat mengukur data secara tepat.

\section{Uji Realibilitas}

Berdasarkan hasil pengujian realibilitas dalam penelitian ini yaitu dengan menggunakan uji statistik Cronbach Alpha, dengan pedoman pengukuran adalah jika nila koefisien alpa diatas 0,6 (Ghozali, 2005). Hasil ujian dapat dilihat pada tabel berikut:

Tabel 3. Hasil Uji Realibitas

\begin{tabular}{|l|l|l|l|l|}
\hline Variabel & $\begin{array}{l}\text { Jumlah } \\
\text { Pertanyaan }\end{array}$ & $\begin{array}{l}\text { Cronbach } \\
\text { Alpha }\end{array}$ & $\begin{array}{l}\text { Batasan } \\
\text { minimum }\end{array}$ & Keterangan \\
\hline Illusions of control & 4 & 0.746 & 0.6 & Reliabel \\
\hline Overconfidence & 6 & 0.855 & 0.6 & Reliabel \\
\hline Emotion & 6 & 0.841 & 0.6 & Reliabel \\
\hline $\begin{array}{l}\text { Pengambilan keputusan } \\
\text { investasi }\end{array}$ & 4 & 0.813 & 0.6 & Reliabel \\
\hline
\end{tabular}

Tabel 4.3 menunjukan bahwa instrumen variabel penelitian adalah reliable, karena Cronbach alpha hitung $>0,6$. Pada variabel illusions of control memiliki nilai Cronbach Alpha sebesar 0.746 , variabel overconfidence memiliki nilai Cronbach Alpha sebesar 0.855, variabel emotion memiliki Cronbach Alpha
0.841, variabel pengambilan keputusan investasi memiliki nilai Cronbach Alpha 0.813.

\section{Uji Hipotesis}

Pengujian hipotesis dalam penelitian ini dilakukan dengan menggunakan model regresi linear berganda (multiple regression), yaitu dilakukan melalui hasil uji statistik t.

Tabel 4. Coefficients ${ }^{a}$

\begin{tabular}{|c|c|c|c|c|c|c|c|}
\hline \multirow[b]{2}{*}{ Model } & \multicolumn{2}{|c|}{ Unstandardized Coefficients } & \multirow{2}{*}{$\begin{array}{c}\begin{array}{c}\text { Standardized } \\
\text { Coefficients }\end{array} \\
\text { Beta }\end{array}$} & \multirow[b]{2}{*}{$\mathrm{t}$} & \multirow[b]{2}{*}{ Sig. } & \multicolumn{2}{|c|}{ Collinearity Statistics } \\
\hline & B & Std. Error & & & & Tolerance & VIF \\
\hline 1 (Constant) & 13,741 & 1,817 & & 7,564 & , 000 & & \\
\hline Total $x 1$ &,- 092 & ,137 &,- 074 &,- 670 & ,505 & ,900 & 1,111 \\
\hline Total $x 2$ & , 174 & ,060 & ,355 & 2,918 & ,005 & ,735 & 1,360 \\
\hline Total x3 &,- 127 & ,055 &,- 273 & $-2,324$ & ,023 & ,789 & 1,268 \\
\hline
\end{tabular}

$Y=13,741-0,092$ IOC $+0,174$ OV- 0,127 EM+e

Untuk menguji keberartian model regresi untuk masing-masing variabel secara parsial dapat diperoleh dengan menggunakan uji t. Berdasarkan output dapat disimpulkan bahwa variabel Illusions of Control memberi pengaruh negatif yang tidak signifikan terhadap pengambilan keputusan investasi.
Hal ini karena nilai koefisien (B) yang negatif dan nilai $p$-value (sig.) yang lebih dari 0,05 . Sebaliknya variabel Overconfidence memberi pengaruh positif yang signifikan terhadap pengambilan keputusan investasi. Hal ini karena nilai koefisien (B) yang positif dan nilai $p$-value (sig.) yang lebih kecil dari 0,05 . Sedangkan variabel Emotion memberi 
pengaruh negatif yang signifikan terhadap pengambilan keputusan investasi. Hal ini karena nilai koefisien (B) yang negatif dan nilai p-value (sig.) yang lebih kecil dari 0,05.

\section{E. Uji Statistik F}

Pengujian signifikasi simultan (uji F) dilakukan untuk menunjukkan apakah semua variabel indepeden yang digunakan dalam model regeresi mempunyai pengaruh yang signifikan secara bersama- sama terhadap variabel dependen. Hasilnya dapat dilihat pada tabel berikut :

Tabel 5. Uji Simultan (F Test)

\begin{tabular}{|rl|r|r|r|r|r|}
\hline \multicolumn{1}{|c|}{ ANOVA $^{\text {b }}$} \\
\hline 1 & $\begin{array}{c}\text { Sum of } \\
\text { Sodel }\end{array}$ & Squares & df & Mean Square & $F$ & Sig. \\
\hline 1 & Regression & 25,197 & 3 & 8,399 & 3,309 &, $024(\mathrm{a})$ \\
& Residual & 208,117 & 82 & 2,538 & & \\
& Total & 233,314 & 85 & & & \\
\hline
\end{tabular}

a. Predictors: (Constant), Total EM , Total IOC, Total OV

b. Dependent Variable: Total PK

Uji F digunakan untuk menguji keberartian semua variable bebas secara bersama-sama terhadap variable terikat. Dari hasil perhitungan statistic dengan menggunakan SPSS diperoleh $F$ hitung $=3,309$ dengan tingkat signifikansi 0,024 (tingkat signifikansi lebih kecildari 0,05). Hal ini berarti bahwa hipotesis yang menyatakan bahwa variabel illusions of control, overconfidence, dan emotion secara bersama-sama mempengaruhi pengambilan keputusan investasi diterima.

\section{F. Uji statistik $\mathbf{t}$}

Uji statistik $t$ digunakan untuk mengetahui ada atau tidaknya pengaruh masing-masing variabel indepeden secara individual terhadap variabel dependen yang diuji pada tingkat signifikan 0.05.Jika nilai probability $t$ lebih besar dari 0.05 , maka Ho diterima.

Tabel 6. Coefficients ${ }^{a}$

\begin{tabular}{|c|c|c|c|c|c|c|c|}
\hline \multirow[b]{2}{*}{ Model } & \multicolumn{2}{|c|}{$\begin{array}{l}\text { Unstandardized } \\
\text { Coefficients }\end{array}$} & \multirow{2}{*}{\begin{tabular}{|c|}
$\begin{array}{c}\text { Standardized } \\
\text { Coefficients }\end{array}$ \\
Beta \\
\end{tabular}} & \multirow[b]{2}{*}{$\mathrm{t}$} & \multirow[b]{2}{*}{ Sig. } & \multicolumn{2}{|c|}{$\begin{array}{l}\text { Collinearity } \\
\text { Statistics }\end{array}$} \\
\hline & B & Std. Error & & & & $\begin{array}{c}\text { Toleranc } \\
\mathrm{e}\end{array}$ & VIF \\
\hline 1(Constant) & 13,741 & 1,817 & & 7,564 &, 000 & & \\
\hline Total IOC &,- 092 & ,137 &,- 074 &,- 670 &, 505 & ,900 & 1,111 \\
\hline Total OV & ,174 & ,060 & ,355 & 2,918 & ,005 & ,735 & 1,360 \\
\hline Total EM &,- 127 & ,055 &,- 273 & $-2,324$ & ,023 & ,789 & 1,268 \\
\hline
\end{tabular}

a. Dependent Variable: Total PK

Berdasarkan output dapat disimpulkan bahwa variabel illusions of control berpengaruh negatif tidak signifikan terhadap pengambilan keputusan. Hal ini karena nilai koefisien (B) yang negatif dan nilai $p$-value (sig.) lebih dari 0,05. Sedangkan
Overconfidence berpengaruh positif signifikan. Hal ini karena nilai koefisien (B) yang positif dan nilai $p$-value(sig.) yang lebih kecil dari 0,05, dan emotion berpengaruh negatif signifikan, Hal ini karena nilai koefisien (B) 
yang negatif dan nilai $p$-value(sig.) yang lebih kecil dari 0,05

Dari hasil pengujian diperoleh variabel Illusion Of Control secara statistik menunjukan hasil yang tidak signifikan pada nilai signifikan lebih besar dari a $(0,505>0,05)$. Sehingga variabel Illusions Of Control tidak berpengaruhsignifikan terhadap pengambilan keputusan investasi yang berarti $\mathbf{H a}_{\mathbf{1}}$ ditolak. Dalam hasil dari penelitian ini mendapati bahwa hubungan Illusions of control negatif tidak signifikan terhadap pengambilan keputusan investasi,perbedaan tersebut membuktikan bahwa dalam mengambil keputusan, seseorang yang mempunyai illusi dapat mengontrol apa yang mereka putuskan belum tentu hasilnya sesuai dengan apa yang telah dibayangkan. Apabila seseorang memiliki illusions of control yang tinggi pada suatu kegiatan seharusnya seseorang tersebut kurang hati-hati dalam tindakannya, namun kenyataannya dalam penelitian ini sebagian responden tetap berhati-hati dalam setiap keputusannya dalam berinvestasi.

Perbedaan ini dimungkinkan dapat terjadi karena pasar saham di Indonesia merupakan pasar efisien berbentuk lemah (Husnan, 1991). Fama (1970) menjelaskan bahwa pasar modal efisien berbentuk lemah adalah dimana harga saham sekarang merefleksikan semua informasi historis (seperti harga dan volume perdagangan di masa lalu), oleh karena itu informasi historis tesebut tidak bisa langsung memprediksi perubahan dimasa yang akan datang karena sudah tercermin pada harga saham saat ini. Sehingga walaupun seseorang mempunyai illusion of control yang tinggi mereka masih hati-hati dalam pengambilan keputusan investasinya.

Dari hasil pengujian diperoleh variabel Overconfidence secara statistik menunjukan hasil yang signifikan pada nilai signifikan lebih kecil dari a $(0,005<0,05)$. Sehingga variabel Overconfidence berpengaruh signifikan terhadap pengambilan keputusan investasi yang berarti Ha2 diterima. Dalam penelitian ini mengahasilkan bahwa overconfidence mempunyai hubungan positif signifikan terhadap pengambilan keputusan investasi, yang berarti semakin investor overconfidence maka semakin sering pengambilan keputusan investasi yang dilakukannya.

Dari hasil pengujian diperoleh variabel Emotion secara statistik menunjukan hasil yang signifikan pada nilai signifikan lebih kecil dari $\alpha(0,024<0,05)$. Maka variabel Emotion berpengaruh signifikan terhadap Pengambilan keputusan investasi yang berarti $\mathrm{Ha}_{3}$ diterima. Dalam penelitian ini mengahasilkan bahwa emotion berpengaruh negatif signifikan terhadap pengambilan keputusan investasi, yang berarti seseorang yang mempunyai tingkat emosi yang tinggi maka niat investor untuk berinvestasi semakin rendah. Perbedaan ini dimungkinkan dapat terjadi karena sebagian besar responden belum memiliki pengalaman yang cukup banyak, yaitu terbukti dengan data bahwa sebagian besar responden dalam penelitian ini baru memiliki investasi dengan jangka waktu kurang dari satu tahun.

\section{KESIMPULAN DAN SARAN}

\section{A. Kesimpulan}

Berdasarkan pada data yang diperoleh maupun hasil analisis yang telah dilakukan, maka dapat diambil kesimpulan mengenai Pengaruh illusions of control, overconfidence, dan emotion berpengaruh terhadap pengambilan keputusan investasi pada investor di yogyakartayaitu sebagai berikut :

1. Illusions Of Control berpengaruh negatif secara tidak signifikan terhadap Pengambilan keputusan investasi.

2. Overconfidence berpengaruh positif secara signifikan terhadap Pengambilan keputusan investasi.

3. Emotion berpengaruh negatif secara signifikan terhadap Pengambilan keputusan investasi.

\section{B. Saran}

1. Pada penelitian selanjutnya diharapkan peneliti menambah variabel lain, seperti confirmation bias atau experienced regret yang merupakan bagian dari bias psikologi. 
2. Pada penelitian selanjutnya diharapkan peneliti menambah lagi jumlah responden sehingga hasil yang didapatkan lebih valid.

3. Pada penelitian selanjutnya diharapkan peneliti lain memilih responden yang telah mempunyai pengalaman investasi yang cukup.

\section{DAFTAR PUSTAKA}

Bester, fadila (2009). Behavioral Finance dalam pengambilan keputusan investasi beresiko :studi eksperimen, Skripsi Fakultas Ekonomi UniversitasSebelas Maret.

Fama, E.F.1970. Efficiency Capital Market: A Review of Theory and Empirical Work. Journal of Finance, vol.25 : 383-4I7.

Husnan, Saud.1996. Dasar-dasar Teori Portofolio dan Analisis Sekuritas. Edisi kedua, Yogyakarta : UPP AMP, YKPN.

Langer. E, and J. Roth (1975), “Heads I win, Tails it's chance: the illusions of control as a function of the sequence of outcomes in a purely chance task, journal of personality and social psychology" 32: $951-955$

Plous, S., 1993. The Psychology of Judgement and Decision Making. McGraw- Hill, Inc

Puspitaningtyas, Zarah dan Agung W Kurniawan (2012). Prediksi Tingkat Pengembalian Investasi Berupa Devidend Yield Berdasarkan Analisis Financial Ratio. MajalahEKONOMI: Telaah Manajemen, Akuntansi dan Bisnis, Vol. 16, No. I, hal. 89-98.

Ricciardi, Victor and Helen K. Simon. 2000. What is Behavioral Finance?.Working Paper. Social Science Research Network (SSRN).

Nofsinger, Jhon R. 2005. Psychologi of Investing. Second Edition. New Jersey. Precentice-Hall Inc

Nofsinger, John R 2010, The Psychologi oflnvesting Fourth Edition, New Jersey Precentice-Hall Inc. 